Article

\title{
Oral Administration of Fucoidan Can Exert Anti-Allergic Activity after Allergen Sensitization by Enhancement of Galectin-9 Secretion in Blood
}

\author{
Masashi Mizuno ${ }^{1, * \mathbb{D}}$, Kana Sakaguchi ${ }^{1}$ and Iwao Sakane ${ }^{2}$ \\ 1 Department of Agrobioscience, Graduate School of Agricultural Science, Kobe University, Kobe 657-8501, \\ Japan; cn.tt.346@gmail.com \\ 2 Central Research Institute, ITO EN, Ltd.; 21 Mekami, Makinohara, Shizuoka 421-0516, Japan; \\ i-sakane@itoen.co.jp \\ * Correspondence: mizuno@kobe-u.ac.jp; Tel./Fax: +81-78-803-5835
}

Received: 25 December 2019; Accepted: 6 February 2020; Published: 9 February 2020

\begin{abstract}
A previous study revealed that fucoidan inhibited mast cell degranulation through the upregulation of galectin-9 in blood. The purpose of this study is to elucidate its mechanism using ovalbumin (OVA) induced anaphylaxis model mice (BALB/c, Female, 5-week-old) and mast cell line (RBL-2H3 cells). Oral administration of fucoidan after sensitization with $\mathrm{OVA} / \mathrm{Al}(\mathrm{OH})_{3}$ inhibited reduction of rectal temperature induced by activation of mast cells. Fucoidan increased galectin-9 mRNA expression only in colonic epithelial cells. These results suggested that fucoidan could suppress the allergic symptoms in sensitized mice by inducing galectin-9 production from colonic epithelial cells. In addition, to check the influence of galectin 9 on the degranulation of mast cells, RBL-2H3 cell lines were treated directly with recombinant galectin-9. As expected, galectin-9 inhibited degranulation of RBL-2H3 cells pre-bound with IgE. Moreover, the residual amounts of IgE on RBL-2H3 cells were decreased by an addition of galectin-9. It was demonstrated that galectin-9 could remove $\mathrm{IgE}$ even if IgE was already bound to mast cells and suppress the mast cells degranulation induced by antigen. This study shows that fucoidan might become an effective therapeutic agent for patients already developed type I allergic diseases.
\end{abstract}

Keywords: Anaphylaxis; fucoidan; galectin-9; mast cell; type I hypersensitivity

\section{Introduction}

Allergy is the abnormal immune reaction against specific substances (allergens) contained in foods, pollens, animal dander, latex, house-dust-mite fecal particle and so on [1]. Allergy can be classified into four types from I to IV, according to difference in pathogenic mechanisms [2,3]. Type I allergy, which is characterized with immediate hypersensitivity reactions, is mediated by interaction between immunoglobulin $\mathrm{E}$ ( $\mathrm{IgE}$ ) and antigen resulting in release of mediators including histamine. Development of type I allergy is associated with that of some immune cells, especially mast cells. In the beginning stage, antigens are taken up and processed by antigen-presenting cells (APCs) such as dendritic cells (DCs) $[4,5]$. The degraded antigens are presented by major histocompatibility complex class II (MHC II) to T cell receptors (TCRs) on naïve CD4 ${ }^{+} \mathrm{T}$ cells $[4,6]$. Thus $\mathrm{CD} 4^{+} \mathrm{T}$ cells are activated and develop into type $2 \mathrm{~T}$ helper (Th2) cells [6]. Th2 cells secrete Th2 cytokines such as interleukin (IL)-4 and IL-13, which are responsible for class switching of immunoglobulin from IgM to IgE in B cells [7]. Antigen-specific IgE produced by the B cells sensitizes the mast cells by its binding to the high-affinity receptor for $\operatorname{IgE}$ ( $\mathrm{F} c \varepsilon R I)$ expressed at the surface of mast cells. When the antigen is recognized again by antigen-specific IgE on Fc\&RI, crosslinking of IgE-FcERI complexes is caused on mast cells. The complex induces activation of mast cells and then a number of inflammatory mediators, including histamine, 
lipid-derived mediators, cytokines and chemokines are released from mast cells [7]. These mediators induce allergic reaction, such as tissue swelling, erythema and sneezing [1]. Type I allergic diseases, including food allergy, allergic rhinitis and asthma, are major health problems around the world and patients suffering from these diseases are ever increasing, so that effective therapy for type I allergy is required to cure them.

Galectin-9, which is one of the lectins that binds $\beta$-galactoside, is produced in various tissues such as intestine, liver, lung and kidney and so on [8]. Some studies demonstrated that galectin-9 exhibits immune modulation effects. For example, galectin-9 prevented autoimmune arthritis by suppressing the generation of Th17 cells and promoting the induction of regulatory T cells [9]. Galctin-9 also enhanced antitumor immunity by increasing T-cell immunoglobulin and mucin domain 3 (Tim-3) ${ }^{+}$ DCs and $\mathrm{CD}^{+} \mathrm{T}$ cells via galectin-9-Tim-3 interaction [10]. Furthermore, it was reported that galectin-9 could suppress the allergic inflammation in a mouse model of allergic asthma [11]. Recently, it has been revealed that galectin-9 could bind IgE and suppress the mast cell activation [12].

Fucoidan, a kind of sulfated polysaccharide obtained from some brown algae, is mainly composed of fucose and sulfated fucose and sometimes contains other sugars, such as mannose, glucose, galactose and xylose [13]. It has been shown that fucoidan exhibited various biological activities, such as antitumor, immunomodulatory [14-16], anti-thrombotic [17-19] and antioxidant activities [20]. Fucoidan, which is contained in Saccharina japonica, is exclusively composed of fucose and sulfated fucose. It was reported that fucoidan is hardly absorbed in intestinal tract and excreted in the feces [17]. A previous study reported that oral administration of fucoidan exhibited anti-allergic effects, whereas its intraperitoneal administration showed no effect [21]. Moreover, it was demonstrated that this anti-allergic activity was due to secrete galectin-9 in blood through intestinal epithelial cells. It was also shown that the intravenous administration of anti-galectin-9 antibody canceled the suppressive effect of fucoidan in the passive cutaneous anaphylaxis (PCA) model. These results suggest that fucoidan might suppress activation of mast cells through promoting production of galectin- 9 from intracellular epithelial cells (IECs). Niki et al. reported that recombinant galectin-9 was able to suppress degranulation of a mast cell line, RBL-2H3 cell, not only after but also before IgE stimulation to the cells [12]. Therefore, it was assumed that galectin-9 could bind to IgE on surface of mast cells and suppress the activation of mast cells induced by antigen.

In this study, the efficacy of fucoidan as therapeutic agent antagonizing type I allergy was examined in ovalbumin (OVA) sensitized mice and investigated in its suppressive mechanism by focusing on the degranulation of mast cells.

\section{Materials and Methods}

\subsection{Reagents}

Eagle's Minimum Essential Medium (MEM) was purchased from Nissui Pharmaceutical (Tokyo, Japan). Blocking One, Chemi-Lumi One super and Sepasol RNA I super $G$ were purchased from Nakarai Tesque (Kyoto, Japan). Anti-dinitrophenyl (DNP) IgE, $p$-nitrophenyl $N$-acetyl- $\beta$-D-glucosaminide, DNP-albumin and Dulbecco's Modified Eagle's Medium Nutrient Mixture F-12 Ham (DMEM/F12) were purchased from Sigma-Aldrich (St Louis, MO, USA). Fetal bovine serum (FBS) was purchased from HyClone Laboratories, Inc. (Logan, UT, USA). RPMI 1640 medium was purchased from Life Technologies (Carlsbad, CA, USA). Recombinant mouse galectin-9 was purchased R\&D Systems (Minneapolis, MN, USA). Anti-mouse galectin-9 antibody was purchased from Santa Cruz Biotechnology (Dallas, TX, USA). Anti-mouse IgE and anti-goat IgG-HRP antibodies were purchased from Bethyl Laboratories (Montgomery, AL, USA). Other ordinary chemicals and reagents were commercially available with guaranteed quality. 


\subsection{Mice}

Female 5-week-old BALB/c mice were purchased from Japan SLC (Shizuoka, Japan). The mice were fed in an air-conditioned animal room at $25 \pm 1{ }^{\circ} \mathrm{C}$ and acclimated for 7 days before experiments, maintained in filter-top cages in specific pathogen-free conditions in Kobe University Life-Science Laboratory with free access to laboratory chow and water ad libitum. All animal experiments were approved and carried out in accordance with the Animal Experiment Ethnics Committee of Kobe University (registration number: 28-11-01).

\subsection{Cell Culture}

Rat basophilic leukemia cell line, RBL-2H3, were cultured in dishes in Eagle's MEM supplemented with $10 \%(v / v)$ heat-inactivated FBS $\left(57^{\circ} \mathrm{C}, 30 \mathrm{~min}\right), 100 \mu \mathrm{g} / \mathrm{mL}$ streptomycin, $100 \mathrm{U} / \mathrm{mL}$ penicillin and $2 \mathrm{mM}$ L-glutamine. Cell cultures were incubated at $37^{\circ} \mathrm{C}$ in a $5 \% \mathrm{CO}_{2}$ incubator and used for the experiments with in passage numbers $17-32$. When cells reached $80 \%$ confluence, they were recovered from the culture dish or flask by trypsin digestion after washing with PBS. After centrifuging, the cells were suspended in cell media and cultured in a new dish or flask.

\subsection{Ovalbumin-Induced Allergy Model}

Mice were sensitized by 4 times intraperitoneal injection of $300 \mu \mathrm{L}$ PBS containing $10 \mu \mathrm{g}$ OVA mixed with $1 \mathrm{mg} \mathrm{Al}(\mathrm{OH})_{3}$ adjuvant once in 5 days. Mice were challenged by intravenous injection of OVA ( $5 \mu \mathrm{g} /$ mouse) at 7 days after the 4 th sensitization and their rectal temperature was measured as the indicator of allergy symptoms using a rectal thermometer for mice (AD-1687; A\&D Tokyo, Japan). It has been reported that mast cell released chemical mediator such as histamine by activation and the mediator induced vessel permeability and vasodilatation [22]. Vasodilation has been known to induce hypotension, followed by decrease of body temperature. Thus, decrease of rectal temperature has been commonly used as a marker of systemic allergic symptom [23]. The rectal temperature was measured in $10 \mathrm{~min}$ intervals for $90 \mathrm{~min}$.

\subsection{Oral Administration of Fucoidan to Mice}

Fucoidan was extracted from S. japonica according to the methods reported by Tanino et al. [21,24]. Fucoidan was dissolved in sterile water and administered to mice intragastrically using an iron probe. Oral administration of fucoidan $(60 \mu \mathrm{g} /$ mouse) was started after the 2 nd and 4 th sensitizations and continued by the last day of the experiment.

\subsection{Measurement of Total IgE, OVA-Specific IgE and OVA Specific IgG1}

At one day before the injection of $\mathrm{OVA} / \mathrm{Al}(\mathrm{OH})_{3}$, blood samples were collected from the tail vein. On the final day, whole blood was collected by cardiac puncture. The blood samples were incubated at room temperature for $1 \mathrm{~h}$ at $4{ }^{\circ} \mathrm{C}$ overnight and were centrifuged at 10,000 rpm for $10 \mathrm{~min}$ to obtain the serum. The amount of total IgE, OVA-specific IgE and IgG1 was measured in serum by using BD OptEIA Mouse IgE ELISA Set (BD Bioscience, San Jose, CA, USA), DS Mouse IgE ELISA (OVA) (DS Pharma Biomedical, Osaka, Japan), Anti-Ovalbumin IgG1 (mouse) ELISA kit (Cayman Chemical, Ann Arbor, MI, USA), respectively.

\subsection{Measurement of Galectin-9}

Galectin-9 contents in serum were measured by ELISA assay. Recombinant mouse galectin- 9 (10-500 ng/mL, $100 \mu \mathrm{L} /$ well) or 2-fold diluted samples (100 $\mu \mathrm{L} /$ well) were plated on a 96 well ELISA plate (greiner bio-one, Solingen, Germany) and placed at $4{ }^{\circ} \mathrm{C}$ overnight. The wells were washed with PBS containing $0.05 \%$ Tween 20 (PBST) and blocked with 1\% BSA in PBS for $90 \mathrm{~min}$ at room temperature. The primary antibody for galectin-9 (1:100 in PBST) was added after washing with PBST and incubated for $90 \mathrm{~min}$ at room temperature. The plate was washed with PBST and secondary anti-goat IgG 
antibody (1:1000 in PBST) was added and incubated more for $1 \mathrm{~h}$ at room temperature. The plate was washed again with PBST and the solution was completely removed. Phosphoric and citric buffer (24.3 mM citric acid, $\left.51.4 \mathrm{mM} \mathrm{Na}_{2} \mathrm{HPO}_{4}, \mathrm{pH} 5.0\right)$ containing o-phenylenediamine $(0.5 \mathrm{mg} / \mathrm{mL}$ ) and $0.015 \% \mathrm{H}_{2} \mathrm{O}_{2}(100 \mu \mathrm{L} /$ well $)$ was added to the plate and subsequently $4 \mathrm{~N} \mathrm{H}_{2} \mathrm{SO}_{4}(50 \mu \mathrm{L} /$ well $)$ was added to stop the reaction. The absorbance at $492 \mathrm{~nm}$ was measured using a microplate reader.

\subsection{RNA Isolation and Real-Time PCR}

Harvested ilium and colon were washed in ice-cold PBS to remove feces and then cut longitudinally. Their IECs were isolated by scraping using a glass slide. Other tissues were lavaged by PBS and frozen using liquid nitrogen. The tissues were cut into small pieces by scissors. Total RNA was extracted from IECs and tissues using Sepasol RNA I super G. The reverse transcription (RT) was conducted using High-Capacity cDNA Reverse Transcription kit (Life Technologies, Carlsbad, CA, USA). The RT reaction was performed in a thermal cycler (Gene Amp ${ }^{\circledR}$ PCR System 9700, Applied Biosystems, Foster City, CA, USA) at $25^{\circ} \mathrm{C}$ for $10 \mathrm{~min}, 37^{\circ} \mathrm{C}$ for $120 \mathrm{~min}$ and $85^{\circ} \mathrm{C}$ for $5 \mathrm{~s}$. The real-time PCR was performed using a 7500 Fast Real Time polymerase chain reaction (PCR) system (Life Technologies, Carlsbad, CA, USA) using FastStart Universal Probe Master (Rox) (Roche Diagnostics, Basel, Switzerland), in accordance with the manufacturer's standard protocol. Taq Man probes (Life Technologies) were used in real time PCR and the product numbers were given as follows; mouse Galectin-9 Assay ID: Mm00495295_m1, human Galectin-9 Assay ID: Hs00371321_m1. Mouse $\beta$-actin Assay ID: Mm00607939_s1 or human GAPDH Assay ID: Hs99999905_m1 were used as endogenous control. For the relative comparison of mRNA expression levels, the data from real-time PCR were analyzed with a $\Delta \Delta C T$ quantification method and normalized to the amount of $\beta$-actin or GAPDH cDNA as an endogenous control.

\section{9. $\beta$-Hexosaminidase Assay}

To evaluate the influence of galectin-9 on anti-allergic activity, RBL-2H3 cells were studied in accordance with a previous study [25]. The cells were preincubated with recombinant galectin-9 solutions $\left(5 \mu \mathrm{g} / \mathrm{mL}\right.$ in SB; $119 \mathrm{mM} \mathrm{NaCl}, 5 \mathrm{mM} \mathrm{KCl}, 0.4 \mathrm{mM} \mathrm{MgCl}, 1 \mathrm{mM} \mathrm{CaCl}_{2}, 40 \mathrm{mM} \mathrm{NaOH}$, $25 \mathrm{mM}$ PIPES, $5.6 \mathrm{mM}$ glucose, $0.1 \% \mathrm{BSA}, \mathrm{pH} 7.2)$ for $2 \mathrm{~h}$ at $37^{\circ} \mathrm{C}$ before sensitization with $1 \mathrm{mg} / \mathrm{mL}$ anti-DNP IgE overnight. The cells were challenged with $10 \mathrm{ng} / \mathrm{mL}$ DNP-albumin for $10 \mathrm{~min}$ at $37^{\circ} \mathrm{C}$. The supernatant $(50 \mu \mathrm{L})$ was incubated with an equal volume of substrate solution $(5 \mathrm{mM}$ $p$-nitrophenyl- $N$-acetyl- $\beta$-D-glucosaminide in $0.2 \mathrm{M}$ citrate buffer at $\mathrm{pH} 4.5)$ for $1 \mathrm{~h}$ at $37^{\circ} \mathrm{C}$. After adding $100 \mu \mathrm{L} /$ well of stop buffer $(0.2 \mathrm{M}$ Tris, $\mathrm{pH} 8.0)$, the absorbance at $405 \mathrm{~nm}$ was measured using a microplate reader. The percentage of $\beta$-hexosaminidase released into the supernatants was calculated as a percentage of the degranulation group (IgE/Antigen group).

\subsection{Western Blot of IgE Binding Mast Cells}

The cells which were sensitized with anti-DNP IgE and then challenged DNP-albumin for $\beta$-hexosaminidase assay were applied western blot to measure IgE contents binding mast cells. The cells were washed twice with PBS and lysed in RIPA buffer, containing $150 \mathrm{mM} \mathrm{NaCl}, 0.5 \%$ sodium deoxycholate, $0.1 \%$ SDS, $50 \mathrm{mM}$ Tris- $\mathrm{HCl}$ (pH 7.4), $50 \mathrm{mM}$ glycerophosphate, $20 \mathrm{mM} \mathrm{NaF}, 1 \mathrm{mM}$ DTT, $5 \mathrm{mg} / \mathrm{mL}$ leupeptin, aprotinin and $100 \mu \mathrm{M}$ PMSF. Proteins were extracted with $50 \mu \mathrm{L}$ RIPA buffer and quantified by the Lowry assay. Total proteins $(30 \mu \mathrm{g})$ were separated by $10 \%$ SDS-PAGE and transferred onto polyvinylidene fluoride membranes (General Electric, Fairfield, CT, USA). Membranes were blocked with Blocking One at room temperature for $1 \mathrm{~h}$ and incubated with anti-mouse IgE or anti- $\beta$-actin antibodies as the primary antibody at $4{ }^{\circ} \mathrm{C}$ overnight, followed by anti-goat or anti-mouse IgG-HRP antibodies as the secondary antibody at $4{ }^{\circ} \mathrm{C}$ for $1 \mathrm{~h}$. All signals were detected by enhanced chemiluminescence using Chemi-Lumi One super and the intensity of band was quantified using the Image J program. 


\subsection{Statistical Analysis}

Each of the value was expressed as mean \pm standard error. Statistical significance between any two groups was analyzed using Student's $t$-test. Statistical significance between more than two groups was analyzed by one-way ANOVA and Tukey test. Statistical significance was defined as $p<0.05$ and 0.01 .

\section{Results}

\subsection{Anti-Allergic Effect of Fucoidan in OVA-Induced Allergic Mice}

It was reported that the oral administration of fucoidan suppressed PCA reaction [21]. To confirm whether fucoidan affected the Th1/Th2 balance, OVA-induced allergic diseases was orally administered with fucoidan from S. japonica. Oral administration of fucoidan shows no changes in serum total IgE, OVA-specific IgE and IgG1 to be increased by OVA injection at Day 17 (Table 1). These data suggested that fucoidan could not modulate immune response, particularly Th2 dominant. As it has reported that fucoidan stimulates to secrete galectin-9 which has a high affinity to IgE [12], it was assumed that fucoidan possessed anti-allergic property even if $\operatorname{IgE}$ contents did not change. During allergic reactions, mast cells usually undergo degranulation with the release of allergic mediators such as histamine and some proteases. Histamine is carried in the blood to the brain where it stimulates thermoregulatory receptors in the hypothalamus which results in the decrease of body temperature observed during allergic reactions. Measurement of rectal temperature is an easy way of monitoring mice body temperature during allergic reactions. Therefore, the rectal temperature was measured as the other anti-allergic index. As show in Figure 1, the rectal temperature in the sensitization group decreased by $-5.6 \pm 0.2^{\circ} \mathrm{C}$ at $40 \mathrm{~min}$ after challenge of OVA compared to control group, whereas in the $200 \mu \mathrm{g} /$ day fucoidan-treated group, the rectal temperature was only reduced by $-3.8 \pm 0.3^{\circ} \mathrm{C}$ at $30 \mathrm{~min}$ and gradually recovered to almost the same level as those of control group.

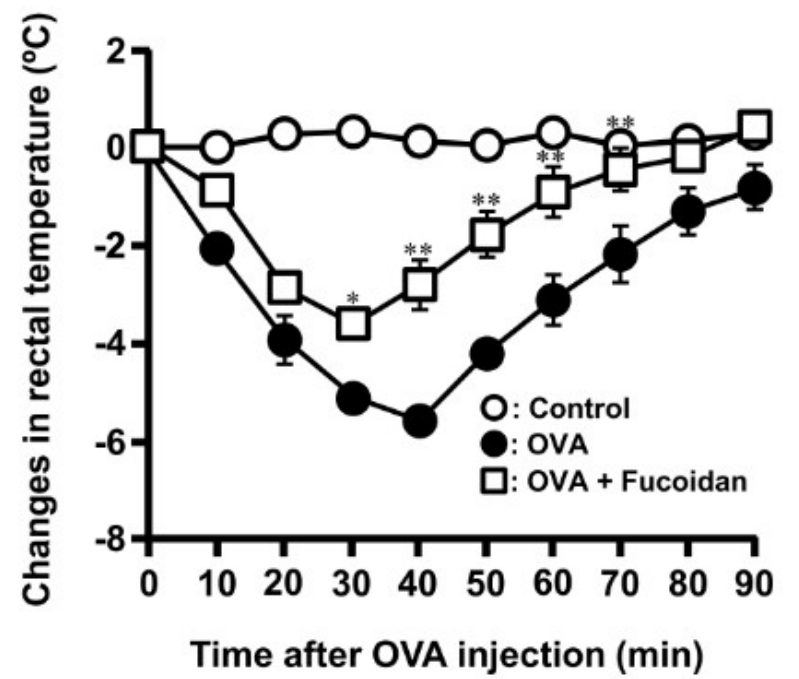

Figure 1. Oral administration of F-fucoidan suppresses the decrease of rectal temperature induced by ovalbumin (OVA) injection. Mice were orally administered F-fucoidan (60 $\mu \mathrm{g} / \mathrm{mouse} /$ day) and immunized by injection of OVA and administrated as described in the Materials and Methods. Rectal temperature was measured every $10 \mathrm{~min}$ for $90 \mathrm{~min}$ immediately following intravenous injection of OVA $\left(5 \mu \mathrm{g} /\right.$ mouse). ${ }^{*} p<0.05,{ }^{* *} p<0.01$ significantly different from the values of the group that was not administrated F-fucoidan and injected OVA (OVA control). Values represent means \pm SE of 4-5 mice in each group. 
Table 1. Effect of F-fucoidan on total IgE, OVA-specific IgE and OVA-specific $\operatorname{IgG}_{1}$ contents in OVA sensitized mice.

\begin{tabular}{lccc}
\hline & Control & OVA & OVA + Fucoidan \\
\hline Total $\operatorname{IgE}(\mu \mathrm{g} / \mathrm{mL})$ & $0.80 \pm 0.16$ & $10.64 \pm 1.28$ & $11.52 \pm 1.51$ \\
\hline OVA specific $\mathrm{IgE}(\mathrm{ng} / \mathrm{mL})$ & N.D. & $661.26 \pm 140.81$ & $550.73 \pm 70.04$ \\
\hline OVA specific $\mathrm{IgG}(\mu \mathrm{g} / \mathrm{mL})$ & N.D. & $882.45 \pm 245.75$ & $1203.28 \pm 162.13$ \\
\hline
\end{tabular}

\subsection{Anti-Allergic Property of Fucoidan after Sensitization of OVA}

It was ascertained that oral administration of fucoidan possesses anti-allergic effect in OVA-induced allergic mice without influence of IgE contents (Figure 1). Moreover, it was demonstrated that galectin-9 secretion in blood plasma was contributed to exert anti-allergy activity in PCA reaction [21]. It was revealed that galectin-9 could have a high-affinity with $\operatorname{IgE}$ and suppress the mast cell activation [12]. Therefore, we hypothesized that fucoidan can fulfil anti-allergic activity after the sensitization of mast cells. As shown in Figure 2A, oral administration of fucoidan was carried out a day after 2nd and 4th sensitization which were corresponding to the period of fucoidan administration for 17 days and 7 days, respectively. Although total IgE and OVA-specific IgE contents increased with the frequency of sensitization, fucoidan administration did not affect predictably their contents (Figure 2B,C). However, a rectal temperature shows the drastic inhibition of decrease by oral administration of fucoidan after OVA sensitization (Figure 3). The rectal temperature at $30 \mathrm{~min}$ after challenge of OVA in the sensitization group decreased by $-1.54 \pm 0.40^{\circ} \mathrm{C}$, whereas in fucoidan-treated group after 17 and 7 days OVA sensitization, the rectal temperature was only reduced by $-0.48 \pm 0.12{ }^{\circ} \mathrm{C}$ and $-0.25 \pm 0.08^{\circ} \mathrm{C}$, respectively. Thus, it was ascertained that oral administration of fucoidan possessed anti-allergic property after sensitization.

\subsection{Glectin-9 Contents in Blood and Lgals9 mRNA Expression in Tissues by Administration of Fucoidan after OVA-Sensitization}

As shown in Figure 3, it was clear the administration of fucoidan after sensitization of OVA shows anti-allergic activity. Previous studies showed that galectin-9 level in blood plasma increased by administration of fucoidan [21]. To examine the relation between anti-allergic effect of fucoidan and galectin-9 secretion, galectin-9 level in blood plasma was measured. As shown in Figure 4, the galectin-9 level was not affected by OVA injection. On the other hand, the tendency to increase galectin- 9 level was observed when fucoidan was administered for 17 days and 7 days after OVA-sensitization. Galectin-9 is widely distributed in various tissues [26] and a large variety of cells including epithelial cells, endothelial cells and immune cells produce galectin-9 [27-29]. As the administration of fucoidan secreted galectin-9 in blood, the galectin-9 mRNA (lgals9) levels of tissues indicated in Figure 5 were measured. Though Lgals9 levels were increased only in colon by oral administration of fucoidan after 2nd and 4th sensitization, no drastic differences recognized in the other tissues. These results suggested that IECs, especially colonic epithelial cells might be responsible for production galectin-9 responded to fucoidan.

\subsection{Effect of Galectin-9 on Degranulation of Mast Cells}

OVA-induced allergic model in Figures 3 and 4 suggested that oral administration of fucoidan might suppress the activation of mast cells by galectin-9 secretion in blood plasma under allergy onset. To ascertain the inhibition of galectin-9 in mast call degranulation by antigen after the sensitization of IgE, RBL-2H3 cells were treated with a recombinant galectin-9 after the sensitization of anti DNP-IgE. The treatment of recombinant galectin-9 $(5 \mu \mathrm{g} / \mathrm{mL})$ suppressed to approximately $75 \%$ of $\beta$-hexosaminidase release from RBL-2H3 induced by DNP-albumin as the antigen (Figure 6). Although it was reported that galectin-9 promoted the apoptosis in various cells including mast cells [30], MTT assay shows no influence on cell viability at less than $10 \mu \mathrm{g} / \mathrm{mL}$ concentration of galectin-9. These results 
indicated that the treatment with galectin-9 to the sensitized mast cells inhibited their degranulation by antigen challenge.

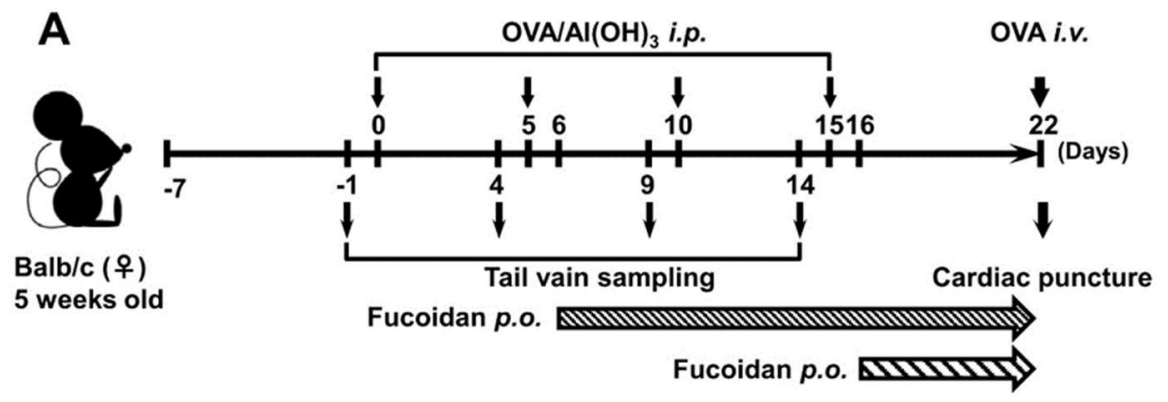

B
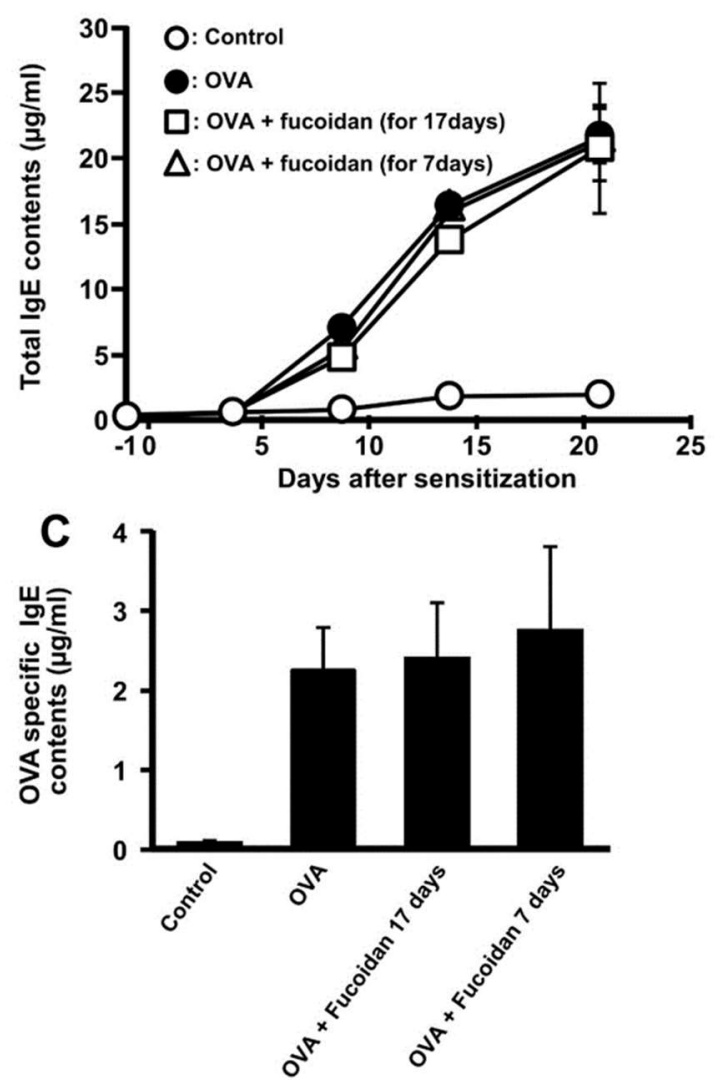

Figure 2. The effect of F-fucoidan on the increase in IgE induced by OVA injection. Mice were immunized by injection of OVA and administrated F-fucoidan orally (60 $\mu \mathrm{g} / \mathrm{mouse} /$ day $)$ as described in the Materials and Methods. (A) Schedule of OVA-induced allergy experiment. (B) Total IgE levels in blood collected from the vain 1 day before OVA injection were measured by ELISA. (C) Whole blood was collected by cardiopuncture 1 day after OVA challenge and plasma was obtained. OVA-specific IgE levels in blood plasma were measured by ELISA. Values represent means \pm SEM of $4-5$ mice in each group.

\subsection{Affinity of Galaectin-9 to Mast Cells against IgE}

It has reported that galectin-9 could have a high-affinity with $\operatorname{IgE}$ and suppress the mast cell activation [12]. Galectin-9 secreted in blood by F-fucoidan administration might possess the property to replace IgE which was already bound on mast cells. To elucidate this hypothesis, IgE contents bound with RBL-2H3 cells which was pre-incubated with anti DNP-IgE overnight and then incubated with galectin-9 were detected by western blot. As shown in Figure 7, the amount of IgE bound to RBL-2H3 decreased in a dose-dependent manner by the recombinant galectin- 9 . The $\operatorname{IgE}$ bound to the 
mast cells incubated with galectin- 9 at the concentration of 5 and $10 \mu \mathrm{g} / \mathrm{mL}$ decreased to $36.7 \%$ and $76.6 \%$, respectively.

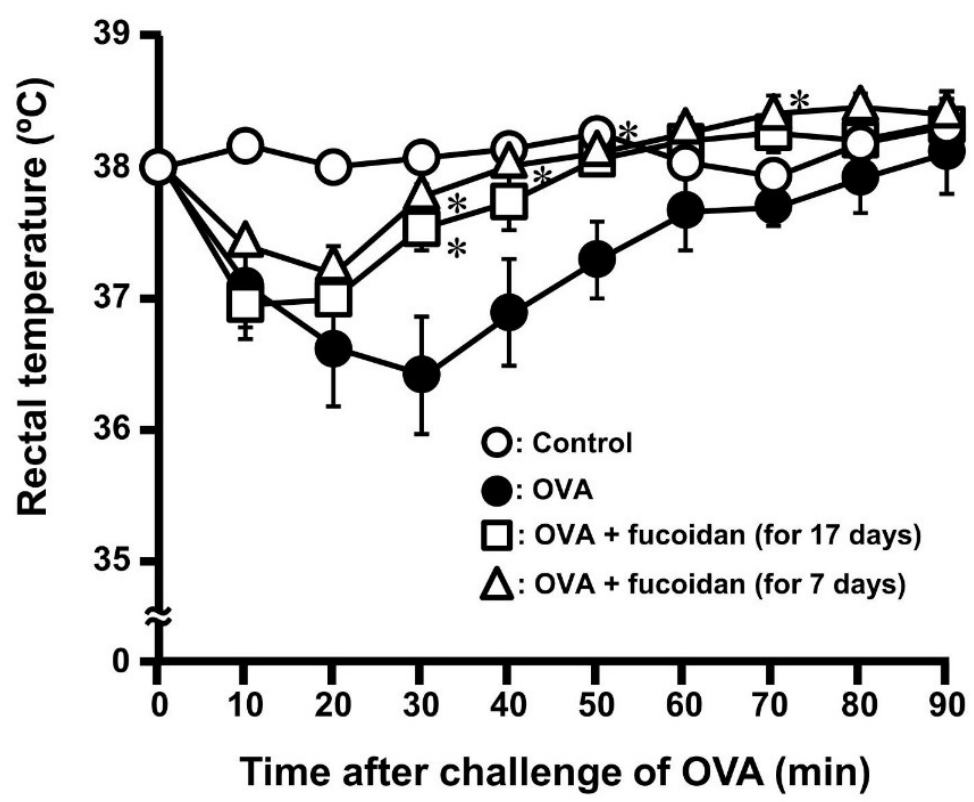

Figure 3. Suppressive effect of F-fucoidan on rectal temperature induced by OVA injection. Mice were immunized by injection of OVA and orally administrated F-fucoidan (60 $\mu \mathrm{g} / \mathrm{mouse} /$ day $)$ as described in the Materials and Methods. Rectal temperature was measured as described in Figure 1. ${ }^{*} p<0.05$ significantly different from the values of the group that was not administrated F-fucoidan and injected OVA (OVA control). Values represent means \pm SEM of 4-5 mice in each group.

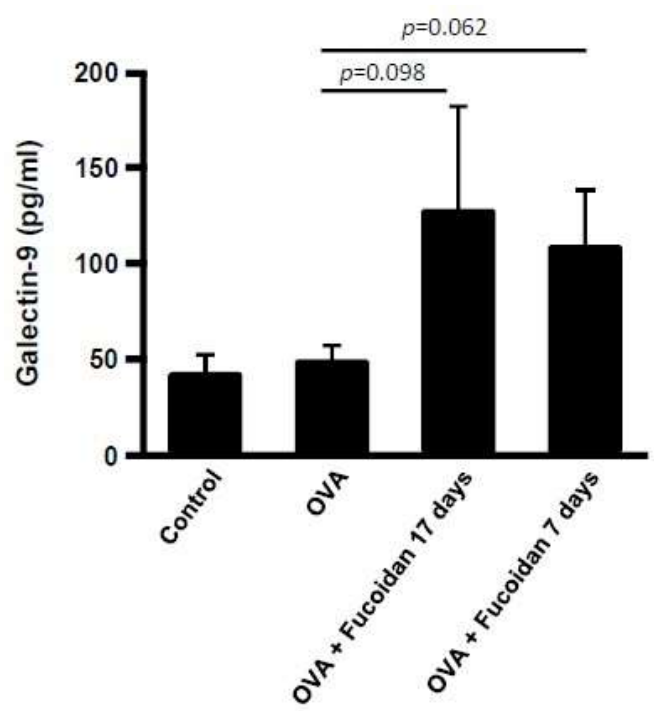

Figure 4. Galectin-9 level in blood plasma of mice administered F-fucoidan. Mice were immunized by injection of OVA and administrated F-fucoidan orally (60 $\mu \mathrm{g} / \mathrm{mouse} /$ day $)$ as described in the Materials and Methods. Whole blood was collected by cardiopuncture 1 day after OVA challenge and plasma was obtained. The concentration of galectin- 9 in blood plasma was measured by ELISA. Values represent means \pm SEM of $4-5$ mice in each group. 

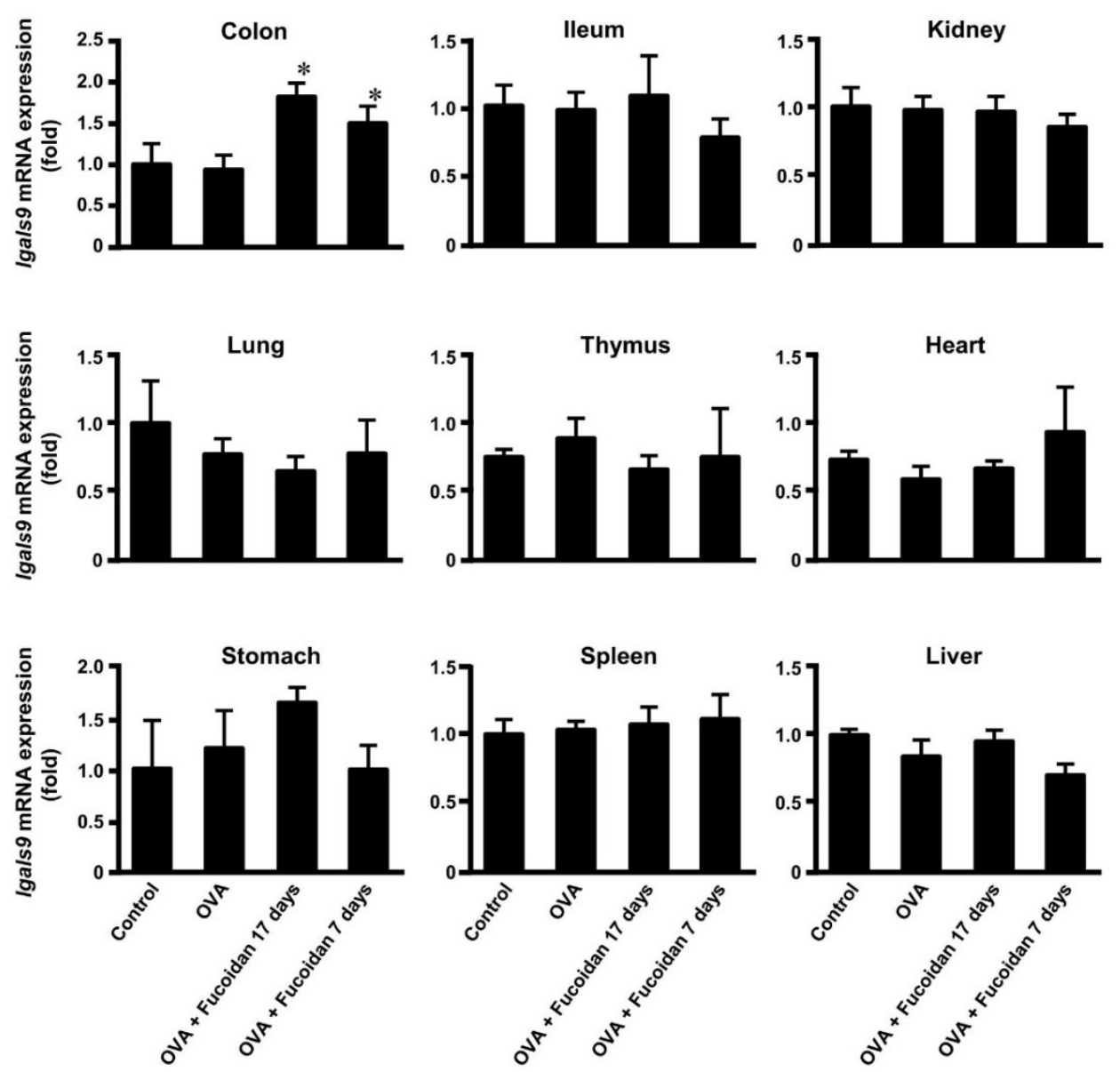

Figure 5. lgals9 mRNA expression in some tissues.Galectin-9 mRNA expression levels in colon, ileum, kidney, lung, thymus, heart, stomach, spleen and liver of mice after measurement of rectal temperature were measured. ${ }^{*} p<0.05$ significantly different from the values of group that was injected OVA and not administrated F-fucoidan (OVA control). Values represent the means \pm SEM of 4-5 mice in each group.

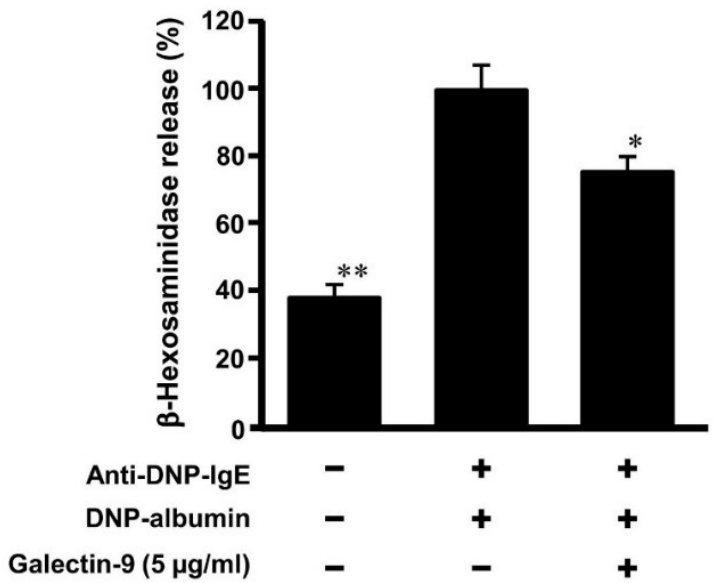

Figure 6. Galectin-9 suppresses the degranulation of mast cells. RBL-2H3 cells were incubated with anti DNP-IgE $(1 \mu \mathrm{g} / \mathrm{mL})$ overnight and then cells were incubated with or without recombinant galectin-9 for $2 \mathrm{~h}$. Degranulation of RBL-2H3 cells was evoked by DNP-albumin as an antigen. The percentage of $\beta$-hexosaminidase release was calculated as a percentage of the group added IgE without galectin-9. ${ }^{*} p<0.05,{ }^{* *} p<0.01$ significantly different from the values of group that was added IgE and incubated without recombinant galectin-9. Values represent the means $\pm \operatorname{SEM}(n=3)$. 


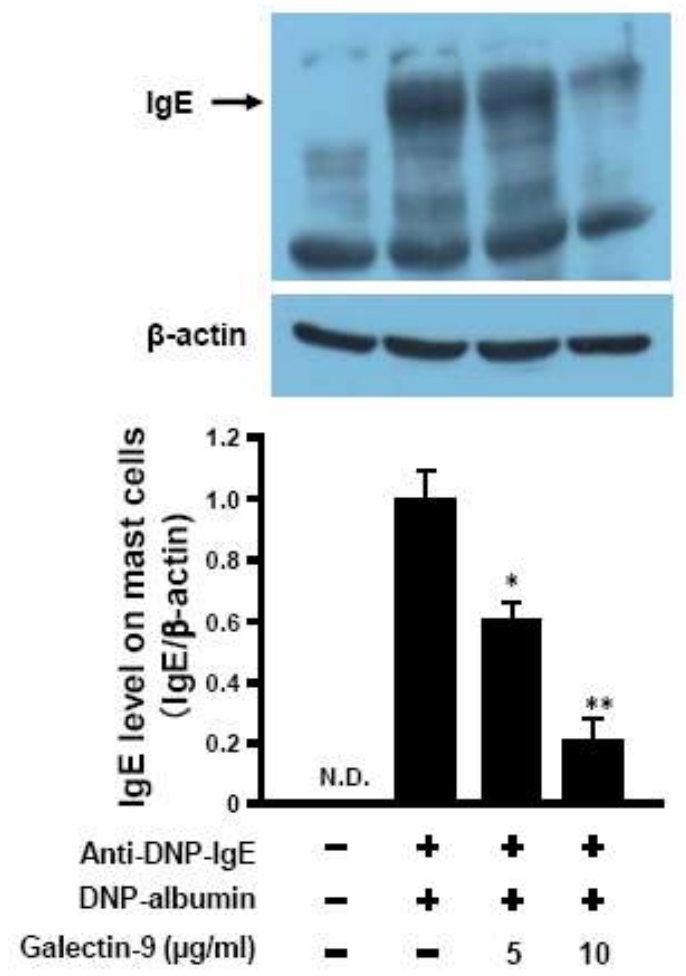

Figure 7. Galectin-9 decreases IgE contents on mast cells. RBL-2H3 cells were incubated with anti DNP-IgE $(1 \mu \mathrm{g} / \mathrm{mL})$ overnight and then incubated with or without recombinant galectin- 9 for $2 \mathrm{~h}$. The cells were collected and lysed to obtain the proteins. IgE level in the samples were measured by western blotting analysis. ${ }^{*} p<0.05,{ }^{* *} p<0.01$ significantly different from the values of group that was added $\mathrm{IgE}$ and incubated without recombinant galectin-9. Values represent the means $\pm \operatorname{SE}(n=3)$.

\section{Discussion}

The reaction of type I allergy is sorted 2 phase; induction phase and effector phase. In induction phase, antigen presentation induces differentiation of naïve helper T (Th) cells to Th2 cells and Th2 polarization promotes antigen-specific IgE production by B cells. The increased IgE binds FceRI on mast cells in inflamed site. In effector phase, antigen-sensitized mast cells are activated via cross-linking of IgE-FceRI by re-invasion of antigen. Therefore, it is predicted to be important for suppression of allergic symptoms that Th2 polarization and IgE generation are inhibited or the release of inflammatory mediators is decreased directly by suppression of mast cells activation.

A number of studies reported that some food factors including flavonoids [31], fatty acids [32] and polysaccharides [33] exhibited anti-allergic effects. Fucoidan, dietary polysaccharide obtained from brown sea algae, had anti-allergic effects by altering Th1/Th2 balance and preventing IgE production from B cells when it was intraperitoneally administered [29,34,35]. However, there are few reports which indicate the effects of oral administration of fucoidan on allergic symptoms.

Previous studies showed that a continuous oral administration of F-fucoidan from S. japonica prior to the sensitization to mice moderated allergic symptoms by suppression of mast cells activation, whereas the oral administration of F-fucoidan did not affect IFN-g and IL-4 productions from splenocyte and the levels of total IgE and OVA-specific IgE in blood [21]. As shown in Figures 2 and 3, the oral administration of F-fucoidan to mice already sensitized with OVA could suppress rectal temperature with no influence in the total IgE and OVA-specific IgE levels in blood plasma as well as the previous report. Moreover, it was revealed that the anti-allergic effect of F-fucoidan was not observed when mice were intraperitoneally administrated F-fucoidan. Accordingly, F-fucoidan was interacted with the intestinal tract to exert its anti-allergic effect. As shown in Figure 5, galectin-9 mRNA increased 
only on colonic epithelial cells by F-fucoidan administration, suggesting that colonic epithelial cells might possibly influence production of galectin-9 in response to F-fucoidan.

It was reported that galectin-9 bound to $\mathrm{IgE}$ with high affinity and suppressed the degranulation of mast cells [12]. This suppression in mast cells degranulation was caused when the cells were incubated with galectin-9 not only before but also after IgE addition. In this study, mast cells were once sensitized with IgE, washed to remove free IgE and then incubated with galectin- 9 to test if $\operatorname{IgE}$ once attached on mast cells was antagonized by galecton- 9 to reduce the degranulation. As the results shown in Figure 6, galectin-9 suppressed degranulation of sensitized mast cells. Furthermore, the level of IgE attached on mast cells was decreased when sensitized mast cells were incubated with galectin-9 (Figure 7). The results suggested that galectin-9 could remove IgE from the mast cells and hence the mast cells activation was suppressed.

Galectin-9 mRNA in IECs and serum galectin-9 levels increased by dietary supplementation with galacto- and fructo-oligosaccharides and Bifidobacterium breve M-16V and the increase was correlated with the prevention of allergic symptoms in mice [36]. In this study, galectin-9 mRNA in colonic epithelial cells of OVA-sensitized mice only increased after the treatment with F-fucoidan, although OVA administration did not influence the galectin-9 mRNA (Figure 5). Similar trend was observed in galectin-9 level in blood plasma (Figure 4). The present study demonstrated that F-fucoidan enhanced the production of galectin-9 in colonic epithelial cells, which suppressed the activation of the mast cells through decrease in IgE attached on mast cells. These findings suggest that galectin-9 induced by F-fucoidan could restore the mast cells sensitized by allergens and that F-fucoidan could have a promising potential as a therapeutic agent for patients with allergic diseases.

Author Contributions: Conceived and designed the experiments: M.M. Performed the experiments: K.S.; I.S. Analyzed the data: K.S.; I.S. Contributed reagents/materials/analysis tools: K.S.; I.S.; M.M. Wrote the paper: K.S.; M.M. All authors have read and agreed to the published version of the manuscript.

Funding: This work was funded by JSPS KAKENHI Grant Number JP18K19741.

Conflicts of Interest: The authors declare no conflict of interest.

\section{Abbreviations}

APCs, Antigen-presenting cells; DCs, dendritic cells; DNP, dinitrophenyl; ELISA, Enzymed-linked immunocorbent assay; FceRI, High-affinity IgE receptor; IECs, intracellular epithelial cells; IgE, Immunoglobulin E; MEM, Eagle's minimum essential medium; OVA, Ovalbumin; PBS, Phosphate buffered saline; PBST, Phosphate buffered saline with Tween 20; PCA, passive cutaneous anaphylaxis; TCRs, T cell receptors; Th2, Type 2 T helper; Tim-3, T-cell immunoglobulin and mucin domain 3.

\section{References}

1. Galli, S.J.; Tsai, M.; Piliponsky, A.M. The development of allergic inflammation. Nature 2008, 454, 445-454. [CrossRef] [PubMed]

2. Madore, A.M.; Laprise, C. Immunological and genetic aspects of asthma and allergy. J. Asthma Allergy 2010, 3, 107-121. [PubMed]

3. Rajan, T.V. The Gell-Coombs classification of hypersensitivity reactions: A re-interpretation. Trends Immunol. 2003, 24, 376-379. [CrossRef]

4. Gould, H.J.; Sutton, B.J. IgE in allergy and asthma today. Nat. Rev. Immunol. 2008, 8, 205-217. [CrossRef]

5. Galli, S.J.; Tsai, M. IgE and mast cells in allergic disease. Nat. Med. 2013, 18, 693-704. [CrossRef]

6. Geha, R.S.; Jabare, H.H.; Brodeur, S.R. The regulation of immunoglobulin E class-switch recombination. Nat. Rev. Immunol. 2003, 3, 721-732. [CrossRef]

7. Larche, M.; Akdis, C.A.; Valenta, R. Immunological mechanism of allergen-specific immunotherapy. Nat. Rev. Immunol. 2006, 6, 761-771. [CrossRef]

8. Wada, J.; Kanwar, Y.S. Identification and characterization of galectin-9, novel $\beta$-galactoside-binding mammalian lectin. J. Biol. Chem. 1997, 272, 6078-6086. [CrossRef] 
9. Seki, M.; Oomizu, S.; Skata, K.M.; Sakata, A.; Arikawa, T.; Watanabe, K.; Ito, K.; Takeshita, K.; Niki, T.; Saita, N.; et al. Galectin-9 suppresses the generation of Th17, promotes the induction of regulatory T cells, and regulates experimental autoimmune arthritis. Clin. Immunol. 2008, 127, 78-88. [CrossRef]

10. Nagahara, K.; Arikawa, T.; Oomizu, S.; Kontani, K.; Nobumoto, A.; Tateno, H.; Watanabe, K.; Niki, T.; Katoh, S.; Miyake, M.; et al. Galectin-9 increases Tim- $3^{+}$dendritic cells and CD8 ${ }^{+} \mathrm{T}$ cells and enhances antitumor immunity via galectin-9-Tim-3 interactions. J. Immunol. 2008, 181, 7660-7669. [CrossRef]

11. Katoh, S.; Ishii, N.; Nobumoto, A.; Takeshita, K.; Dai, S.Y.; Shinonaga, R.; Niki, T.; Nishi, N.; Tominaga, A.; Yamauchi, A.; et al. Galectin-9 inhibits CD44-hyaluronan interaction and suppresses a murine model of allergic asthma. Am. J. Respir. Crit. Care Med. 2007, 176, 27-35. [CrossRef] [PubMed]

12. Niki, T.; Tsutsui, S.; Hirose, S.; Aradono, S.; Sugimoto, Y.; Takeshita, K.; Nishi, N.; Hirashima, M. Galectin-9 is a high affinity IgE-binding lectin with anti-allergic effect by blocking IgE-antigen complex formation. J. Biol. Chem. 2009, 284, 32344-32352. [CrossRef] [PubMed]

13. Li, B.; Lu, F.; Wei, X.; Zhao, R. Fucoidan: Structure and bioactivity. Molecules 2008, 13, 1671-1695. [CrossRef]

14. Zhuang, C.; Itoh, H.; Mizuno, T.; Ito, H. Antitumor active fucoidan from the brown seaweed, umitoranoo (Sargassum thunbergii). Biosci. Biothnol. Biochem. 1995, 59, 563-567. [CrossRef] [PubMed]

15. Wu, L.; Sun, J.; Su, X.; Yu, Q.; Yu, Q.; Zhang, P. A review about the development of fucoidan in antitumor activity: Progress and challenges. Carbohydr. Polym. 2016, 154, 96-111. [CrossRef] [PubMed]

16. Ale, M.T.; Maruyama, H.; Tamauchi, H.; Mikkelsen, J.D.; Meyer, A.S. Fucoidan from Sargassum sp. and Fucus vesiculosus reduces cell viability of lung carcinoma and melanoma cells in vitro and activates natural killer cells in mice in vivo. Int. J. Biol. Macromol. 2011, 49, 331-336. [CrossRef]

17. Ren, R.; Azuma, Y.; Ojima, T.; Hashimoto, T.; Mizuno, M.; Nishitani, Y.; Yoshida, M.; Azuma, T.; Kanazawa, K. Modulation of platelet aggregation-related eicosanoid production by dietary F-fucoidan from brown alga Laminaria japonica in human subjects. Br. J. Nutr. 2013, 110, 880-890. [CrossRef]

18. Senthilkumar, K.; Manivasagan, P.; Venkatesan, J.; Kim, S.K. Brown seaweed fucoidan: Biological activity and apoptosis, growth signaling mechanism in cancer. Int. J. Biol. Macromol. 2013, 60, 366-374. [CrossRef]

19. Zhao, X.; Guo, F.; Hu, J.; Zhang, L.; Xue, C.; Zhang, Z.; Li, B. Antithrombotic activity of oral administered low molecular weight fucoidan from Laminaria Japonica. Thromb. Res. 2016, 144, 46-52. [CrossRef]

20. Rocha de Souza, M.C.; Marques, C.T.; Guerra Dore, C.M.; Ferreira da Silva, F.R.; Oliveira Rocha, H.A.; Leite, E.L. Antioxidant activities of sulfated polysaccharides from brown and red seaweeds. J. Appl. Phycol. 2007, 19, 153-160. [CrossRef]

21. Tanino, Y.; Hashimoto, T.; Ojima, T.; Mizuno, M. F-fucoidan from Saccharina japonica is a novel inducer of galectin-9 and exhibits anti-allergic activity. J. Clin. Biochem. Nutr. 2016, 59, 25-30. [CrossRef] [PubMed]

22. Makabe-Kobayashi, Y.; Hori, Y.; Adachi, T.; Ishigaki-Suzuki, S.; Kikuchi, Y.; Kagaya, Y.; Shirato, K.; Nagy, A.; Ujike, A.; Takai, T.; et al. The control effect of histamine on body temperature and respiratory function in IgE-dependent systemic anaphylaxis. J. Allergy Clin. Immunol. 2002, 110, 298-303. [CrossRef] [PubMed]

23. Brandt, E.B.; Strait, R.T.; Hershko, D.; Wang, Q.; Muntel, E.E.; Scribner, T.A.; Zimmermann, N.; Finkelman, F.D.; Rothenberg, M.E. Mast cells are required for experimental oral allergen-induced diarrhea. J. Clin. Investig. 2003, 112, 1666-1677. [CrossRef] [PubMed]

24. Morita, A.; Tanino, Y.; Ojima, T.; Mizuno, M. Influence of temperature on anti-allergic activity of fucoidan extracted from Saccharina japonica. Food Sci. Technol. Res. 2019, 25, 607-611. [CrossRef]

25. Yamashita, S.; Yokoyama, Y.; Hashimoto, T.; Mizuno, M. A novel in vitro co-culture model comprised of Coco-2/RBL-2H3 cells to evaluate anti-allergic effects of food factors through the intestine. J. Immunol. Methods 2016, 435, 1-6. [CrossRef]

26. Than, N.G.; Romero, R.; Balogh, A.; Karpati, E.; Mastrolia, S.A.; Staretz-Chacham, O.; Hahn, S.; Erez, O.; Papp, Z.; Kim, C.J. Galectins: Double-edged swords in the cross-roads of pregnancy complications and female reproductive tract inflammation and neoplasia. J. Pathol. Transl. Med. 2015, 49, 181-208. [CrossRef]

27. Chen, X.; Song, C.H.; Liu, Z.Q.; Feng, B.S.; Zheng, P.Y.; Li, P.; In, S.H.; Tang, S.G.; Yang, P.C. Intestinal epithelial cells express galectin-9 in patients with food allergy that plays a critical role in sustaining allergic status in mouse intestine. Allergy 2011, 66, 1038-1049. [CrossRef]

28. Alam, S.; Li, H.; Margariti, A.; Martin, D.; Zampetaki, A.; Habi, O.; Cockerill, G.; Hu, Y.; Xu, Q.; Zeng, L. Galectin-9 protein expression in endothelial cells is positively regulated by histone deacetylase 3. J. Biol. Chem. 2011, 286, 44211-44217. [CrossRef] 
29. Oomizu, S.; Arikawa, T.; Niki, T.; Kadowaki, T.; Ueno, M.; Nishi, N.; Yamauchi, A.; Hattori, T.; Masaki, T.; Hirashima, M. Cell surface galectin-9 expressing Th cells regulate Th17 and Foxp ${ }^{+}$Treg development by galectin-9 secretion. PLOS ONE 2012, 7, e48574. [CrossRef]

30. Kojima, R.; Ohno, T.; Iikura, M.; Niki, T.; Hirashima, M.; Iwaya, K.; Tsuda, H.; Nonoyama, S.; Matsuda, A.; Saito, H.; et al. Galectin-9 enhances cytokine secretion, but suppresses survival and degranulation, in human mast cell line. PLoS ONE 2014, 9, e86106. [CrossRef]

31. Kim, J.W.; Lee, J.H.; Hwang, B.Y.; Mun, S.H.; Ko, N.Y.; Kim, D.K.; Kim, B.; Kim, H.S.; Kim, Y.M.; Choi, W.S. Morin inhibits Fyn kinase in mast cells and IgE-mediated type I hypersensitivity response in vivo. Biochem. Pharmacol. 2009, 77, 1509-1512. [CrossRef] [PubMed]

32. Wang, X.; Ma, D.W.; Kang, J.X.; Kulka, M. n-3 Polyunsaturated fatty acids inhibit Fce receptor I-mediated mast cell activation. J. Nutr. Biochem. 2015, 26, 1580-1588. [CrossRef] [PubMed]

33. Ramberg, J.E.; Nelson, E.D.; Sinnott, R.A. Immunomodulatory dietary polysaccharides: A systematic review of the literature. Nutr. J. 2010, 9, 54. [CrossRef] [PubMed]

34. Vo, T.S.; Ngo, D.H.; Kang, K.H.; Jung, W.K.; Kim, S.K. The beneficial properties of marine polysaccharides in alleviation of allergic responses. Mol. Nutr. Food Res. 2015, 59, 129-138. [CrossRef]

35. Yanase, Y.; Hiragun, T.; Uchida, K.; Ishii, K.; Oomizu, S.; Suzuki, H.; Mihara, S.; Iwamoto, K.; Matsuo, H.; Onishi, N.; et al. Peritoneal injection of fucoidan suppresses the increase of plasma IgE induced by OVA-sensitization. Biochem. Biophys. Res. Commun. 2009, 387, 435-439. [CrossRef]

36. de Kivit, S.; Saeland, E.; Kraneveld, A.D.; van de Kant, H.J.; Schouten, B.; van Esch, B.C.; Knol, J.; Sprikkelman, A.B.; van der Aa, L.B.; Knippels, L.M.; et al. Galectin-9 induced by dietary synbiotics is involved in suppression of allergic symptoms in mice and humans. Allergy 2012, 67, 343-352. [CrossRef]

(C) 2020 by the authors. Licensee MDPI, Basel, Switzerland. This article is an open access article distributed under the terms and conditions of the Creative Commons Attribution (CC BY) license (http://creativecommons.org/licenses/by/4.0/). 